\title{
Effect of Foliar Spray of Various Nutrients on Yield Attributes, Yield and Economics of Rainfed Rice
}

\author{
Anand Mohan, Ankit Tiwari* and Bhagwan Singh
}

Department of Agronomy, N. D. University of Agriculture and Technology, Kumarganj, Faizabad-224 229 (UP), India

*Corresponding author

\section{A B S T R A C T}

A field experiment was conducted at Agronomy Research Farm of Narendra Deva University of Agriculture and Technology Kumarganj, Faizabad (U.P.) during kharif season of 2013 to find out the nutrient economy through foliar application of fertilizer and to assess the economic feasibility of various treatments. The experiment was conducted in RBD with 3 replications and 12 treatments of nutrient management modulesviz., $\mathrm{T}_{1}-100 \%$ $\mathrm{RDF}$ as basal, $\mathrm{T}_{2}-100 \% \mathrm{RDF}$ as basal +3 water sprays, $\mathrm{T}_{3}-75 \% \mathrm{RDF}+2.5$ Tonnes $\mathrm{FYM}$,

\begin{tabular}{|c|}
\hline Keywords \\
\hline $\begin{array}{l}\text { Rice, Foliar spray, } \\
\text { Nutrient modules, } \\
\text { Yield, Economics. }\end{array}$ \\
\hline Article Info \\
\hline $\begin{array}{l}\text { Accepted: } \\
\text { 23 September } 2017 \\
\text { Available Online: } \\
10 \text { October } 2017\end{array}$ \\
\hline
\end{tabular}
$\mathrm{T}_{4}-50 \% \mathrm{RDF}+5$ Tonnes FYM, $\mathrm{T}_{5}-50 \% \mathrm{RDF}+3$ foliar sprays of $20 \mathrm{~kg}^{-5} \mathrm{Ura} \mathrm{ha}^{-1}, \mathrm{~T}_{6}-50 \%$ $\mathrm{RDF}+3$ foliar sprays of $20 \mathrm{~kg}$ Urea ha $^{-1}+10 \mathrm{~kg} \mathrm{ZnSO}_{4} \mathrm{ha}^{-1}, \mathrm{~T}_{7}-100 \% \mathrm{RDF}+30 \mathrm{~kg} \mathrm{ZnSO}$ $\mathrm{ha}^{-1}$ as soil application, $\mathrm{T}_{8}-100 \% \mathrm{RDF}+2$ foliar sprays of $5 \mathrm{~kg} \mathrm{FeSO}_{4} \mathrm{ha}^{-1}, \mathrm{~T}_{9}-100 \% \mathrm{RDF}$ +2 foliar sprays of $10 \mathrm{~kg}$ Borax ha ${ }^{-1}, \mathrm{~T}_{10}-100 \% \mathrm{RDF}+2$ foliar sprays of $10 \mathrm{~kg}$ Sulphur $\mathrm{ha}^{-1}, \mathrm{~T}_{11}-100 \% \mathrm{RDF}+2$ foliar sprays of $20 \mathrm{Urea} \mathrm{ha}^{-1}+10 \mathrm{~kg} \mathrm{ZnSO}_{4} \mathrm{ha}^{-1}$ and $\mathrm{T}_{12}-100 \%$ $\mathrm{RDF}+2$ foliar spray of $10 \mathrm{~kg} \mathrm{ZnSO}_{4} \mathrm{ha}^{-1}+5 \mathrm{~kg} \mathrm{FeSO}_{4} \mathrm{ha}^{-1}+10 \mathrm{~kg}^{-1}$ orax ha ${ }^{-1}+10 \mathrm{~kg}$ Sulphur ha ${ }^{-1}$. Treatment $\mathrm{T}_{12}\left(100 \% \mathrm{RDF}+2\right.$ foliar sprays of $10 \mathrm{~kg} \mathrm{ZnSO}_{4} \mathrm{ha}^{-1}+5 \mathrm{~kg}$ $\mathrm{FeSO}_{4} \mathrm{ha}^{-1}+10 \mathrm{~kg}$ Borax ha ${ }^{-1}+10 \mathrm{~kg}$ Sulphur ha $^{-1}$ ) found significantly superior over rest of the treatments in all the aspects. Treatment $\mathrm{T}_{12}(100 \% \mathrm{RDF}+2$ foliar sprays of $10 \mathrm{~kg}$ $\mathrm{ZnSO}_{4} \mathrm{ha}^{-1}+5 \mathrm{~kg} \mathrm{FeSO}_{4} \mathrm{ha}^{-1}+10 \mathrm{~kg}$ Borax ha ${ }^{-1}+10 \mathrm{~kg}$ Sulphur ha ${ }^{-1}$ ) increases all the yield attributing characters viz., number of panicles $\left(378 \mathrm{~m}^{-2}\right)$, length of panicle $(21.60$ $\mathrm{cm})$, number of grains per panicle $(79.20)$ and test weight $(23.10 \mathrm{~g})$ of rice which undoubtedly results in increase in yield of rice crop. Treatment $T_{12}$ found significantly superior and produced higher grain and straw yields as compared to the other treatments. Treatment $T_{12}$ was found economically best in respect to gross return (Rs. 45170) and net return (Rs. 23521) while B:C found best with Treatment $\left(\mathrm{T}_{11}\right)(2.23)$ which was found superior over rest of the treatments.

\section{Introduction}

Rice (Oryza sativa L.) belongs to the family graminae, genus Oryza has two cultivated and 22 wild species. The cultivated species are Oryza sativa and Oryza glaberrima. Oryza sativa is grown all over the world while Oryzagla berrima has been cultivated in West Africa for the last 3500 years. Rice is grown under many different conditions.
Rice is the only cereal crop that can grow in standing water. $57 \%$ of rice is grown on irrigated land, $25 \%$ on rainfed lowland, $10 \%$ on the uplands, $6 \%$ in deep water and $2 \%$ in tidal wetlands of the world. Rice is cultivated world-wide over an area about $156.68 \mathrm{~m}$ ha with an annual production of about 650.19 million tonnes (Anonymous, 2013). In India, 
rice is cultivated on an area of about 39.47 million hectares with an annual production of about 87.10 million tonnes with average productivity of $2207 \mathrm{~kg}$ per hectare. In Uttar Pradesh the area of rice is about 13.84 million hectares and production is 23.64 million tonnes, with productivity of $2358 \mathrm{~kg}$ per hectare. It is the staple food for two thirds of the world's population. Over 2 billion people in Asia alone derive $80 \%$ of their energy needs from rice, which contains $80 \%$ carbohydrates, $7-8 \%$ protein, $3 \%$ fat, and $3 \%$ fiber. Rice protein, though small in amount, is of high nutritional value. Rice bran is used as cattle and poultry feed. Nutrient deficiency is considered as one of the major causes of the declining productivity trends, observed in rice growing countries. Sodic, upland and calcareous coarse-textured soils with low organic matter content suffer from $\mathrm{Fe}$ deficiency. Foliar sprays are widely used to apply nutrients, especially iron and manganese for many crops. Correction of deficiency symptoms usually occurs within the first several days and then the entire field could be sprayed with the appropriate nutrient source.

However, rice has shown signs of fatigue and evidences suggest that a decline in natural resources and micronutrient are two major reasons for reduction of productivity in this system (Prasad 2005).A recent trend in the fertilizer industry to shift from ammonium sulphate to urea and from superphosphate to non-sulphur phosphatic fertilizer may induce more widespread sulphur deficiency in lowland rice. Keeping all above facts in view the present study was undertaken to find out the nutrient economy through foliar application of fertilizer and to assess the economic feasibility of various treatments.

\section{Materials and Methods}

The present investigation entitled "Effect of foliar spray of various nutrients on performance of rainfed rice" was conducted at the Agronomy Research Farm of Narendra Deva University of Agriculture and Technology, Kumarganj, Faizabad (UP). The experiment was conducted during kharif season of the year 2013. The experimental site falls under subtropical climate in IndoGangetic plains having alluvial calcareous soil and lies between $26^{\circ} 47^{\prime}$ North latitude and $82^{\circ} 12^{\prime}$ East longitude at an altitude of 113 $\mathrm{m}$ from mean sea level. The region receives annual rainfall ranging from 1000-1200 mm and 90 per cent of which is received in MidJune to end of September of the region is about $1100 \mathrm{~mm}$ and 90 per cent of which is received from July to September. The expected time of onset of monsoon is between $15^{\text {th }}$ to $25^{\text {th }}$ June. The weekly mean maximum and minimum temperatures during the crop season ranged from $28.9^{0} \mathrm{C}$ to $35.2^{\circ} \mathrm{C}$ and $18.7^{0} \mathrm{C}$ to $36.2^{0} \mathrm{C}$, respectively. The maximum rainfall of $312.3 \mathrm{~mm}$ was recorded in the fourth week of June, 2013. The soil of the experimental field was silt loam, having $\mathrm{pH}$ 8.0, organic carbon 0.35 and Electrical Conductivity 0.23 and available $\mathrm{N}, \mathrm{P}$ and $\mathrm{K}$ $185.0 \mathrm{kgha}^{-1}, 10.2 \mathrm{kgha}^{-1}$ and $215.1 \mathrm{kgha}^{-1}$ respectively. The sowing of rice cultivar NDR-97 was done on $24^{\text {th }}$ June, 2013 at the spacing of $20 \times 10 \mathrm{~cm}$. There were twelve treatment combinations as detailed below:

$\mathrm{T}_{1}-100 \% \mathrm{RDF}$ as basal, $\mathrm{T}_{2}-100 \% \mathrm{RDF}$ as basal +3 water spray, $\mathrm{T}_{3}-75 \% \mathrm{RDF}+2.5$ Tonnes FYM, $\mathrm{T}_{4}-50 \% \mathrm{RDF}+5$ Tonnes FYM, $\mathrm{T}_{5}-50 \% \mathrm{RDF}+3$ foliar spray of $20 \mathrm{~kg}$ Urea $\mathrm{ha}^{-1}, \mathrm{~T}_{6}-50 \% \mathrm{RDF}+3$ foliar spray of $20 \mathrm{~kg}$ Urea ha $^{-1}+10 \mathrm{~kg} \mathrm{ZnSO}_{4} \mathrm{ha}^{-1}, \mathrm{~T}_{7}-100 \% \mathrm{RDF}+$ $30 \mathrm{~kg} \mathrm{ZnSO} \mathrm{Zna}^{-1}$ as soil application, $\mathrm{T}_{8}-100 \%$ $\mathrm{RDF}+2$ foliar spray of $5 \mathrm{~kg} \mathrm{FeSO} 4 \mathrm{ha}^{-1}, \mathrm{~T}_{9}$ $100 \% \mathrm{RDF}+2$ foliar spray of $10 \mathrm{~kg}$ Borax $\mathrm{ha}^{-1}, \mathrm{~T}_{10}-100 \% \mathrm{RDF}+2$ foliar spray of $10 \mathrm{~kg}$ Sulphur ha ${ }^{-1}, \mathrm{~T}_{11}-100 \%$ RDF +2 foliar spray of 20 Urea ha $^{-1}+10 \mathrm{~kg} \mathrm{ZnSO}_{4} \mathrm{ha}^{-1}$ and $\mathrm{T}_{12-}$ $100 \% \mathrm{RDF}+2$ foliar spray of $10 \mathrm{~kg} \mathrm{ZnSO}_{4}$ $\mathrm{ha}^{-1}+5 \mathrm{~kg} \mathrm{FeSO}_{4} \mathrm{ha}^{-1}+10 \mathrm{~kg}$ Borax ha ${ }^{-1}+10$ $\mathrm{kg}$ Sulphur ha ${ }^{-1}$. 
Observations were recorded at harvest stage of Rice. Number of panicles per square meter at harvest was counted by placing a quadrate of $50 \times 50 \mathrm{~cm}$ at three places at random in each plot and total number of panicles per square meter were computed. Five panicles were sampled randomly at maturity stage from each plot and their length was measured and averaged values were recorded in $\mathrm{cm}$. After taking weight selected five panicles were threshed and number of filled grains were counted and there after the mean number of grains per panicle were computed. A composite sample of grains was collected from the produce of each plot after drying and cleaning. Thousand grains were counted from the sample and their weight was recorded in gram. Threshing was done plot-wise manually. The thrashed grains were sun dried to bring the moisture content at a standard level of 14 per cent and cleaned thoroughly before taking the final weight in $\mathrm{kg}$ per plot, which in largely computed as $\mathrm{qha}^{-1}$. The straw yield was computed by deducting the grain yield from the total biomass from each plot and expressed in $\mathrm{qha}^{-1}$. The recovery of grains in total dry matter of crop was considered as harvest index. It was calculated with the help of following formula.

Harvest index $(\%)=\frac{\text { Grain yield }}{\text { Biological yield }} \times 100$

\section{Results and Discussion}

The data on yield attributing characters recorded at harvest stage are presented in (Table 1). All the yield contributing character viz., number of panicle $\mathrm{m}^{-2}$, length of panicle $(\mathrm{cm})$, number of grains panicle ${ }^{-1}$ and test weight were significantly influence of due to various nutrient management modules. The highest number of panicles $\mathrm{m}^{-2}$ was observed with $\mathrm{T}_{12}(100 \% \mathrm{RDF}+2$ foliar spray of $10 \mathrm{~kg}$ $\mathrm{ZnSO}_{4} \mathrm{ha}^{-1}+5 \mathrm{~kg} \mathrm{FeSO}_{4} \mathrm{ha}^{-1}+10 \mathrm{~kg}$ Borax $\mathrm{ha}^{-1}+10 \mathrm{~kg}$ Sulphur ha ${ }^{-1}$ ) which was at par with $T_{10}$ and $T_{11}$ and significantly superior over rest of the treatments. This was mainly due to increase in number of tillers $\mathrm{m}^{-2}$ under balanced doses of nutrients which resulted increase in number of panicles $\mathrm{m}^{-2}$. Similar findings have also been reported by Singh $e t$ al., (1998) and Hollena et al., (2008). The length of panicle was significantly affected by various nutrient management modules.

The maximum panicle length was recorded with application of nutrients management modules of $\mathrm{T}_{12}(100 \% \mathrm{RDF}+2$ foliar spray of $10 \mathrm{~kg} \mathrm{ZnSO}_{4} \mathrm{ha}^{-1}+5 \mathrm{~kg} \mathrm{FeSO}_{4} \mathrm{ha}^{-1}+10 \mathrm{~kg}$ Borax ha ${ }^{-1}+10 \mathrm{~kg}$ Sulphur ha ${ }^{-1}$ ) which was at par with $T_{11}$ and significantly superior over other nutrient management modules. The increase in panicle length may be attributed to more uptake of nutrients under balanced dose of nutrients which increased the sink size visà-vis panicle length as compared to other nutrient management modules. Ramesh et al., (2007) and Singh et al., (1998) have also reported more panicles length with the balanced dose of nutrients.

The number of grains panicle ${ }^{-1}$ significantly influenced by various nutrient management modules. The maximum number of grains panicle $^{-1}$ was found with $\mathrm{T}_{12}(100 \% \mathrm{RDF}+2$ foliar sprays of $10 \mathrm{~kg} \mathrm{ZnSO} \mathrm{Zha}^{-1}+5 \mathrm{~kg}$ $\mathrm{FeSO}_{4} \mathrm{ha}^{-1}+10 \mathrm{~kg}$ Borax ha ${ }^{-1}+10 \mathrm{~kg}$ Sulphur $\mathrm{ha}^{-1}$ ) which were at par with $\mathrm{T}_{10}$ and $\mathrm{T}_{11}$ and significantly superior over other nutrient management modules. These results may be attributed to the fact that balanced nutrients application resulted better growth of root and shoots which resulted higher nutrient uptake and more production of photosynthates and its translocation to sink (spikelets) vis-à-vis filled grain panicle ${ }^{-1}$. These results are in agreement with those of Ramesh et al., (2007) and Shekara et al., (2011). Various nutrient management modules significantly influenced the test weight of rice. 
Table.1 Effect of various nutrient management modules on yield attributes of rice

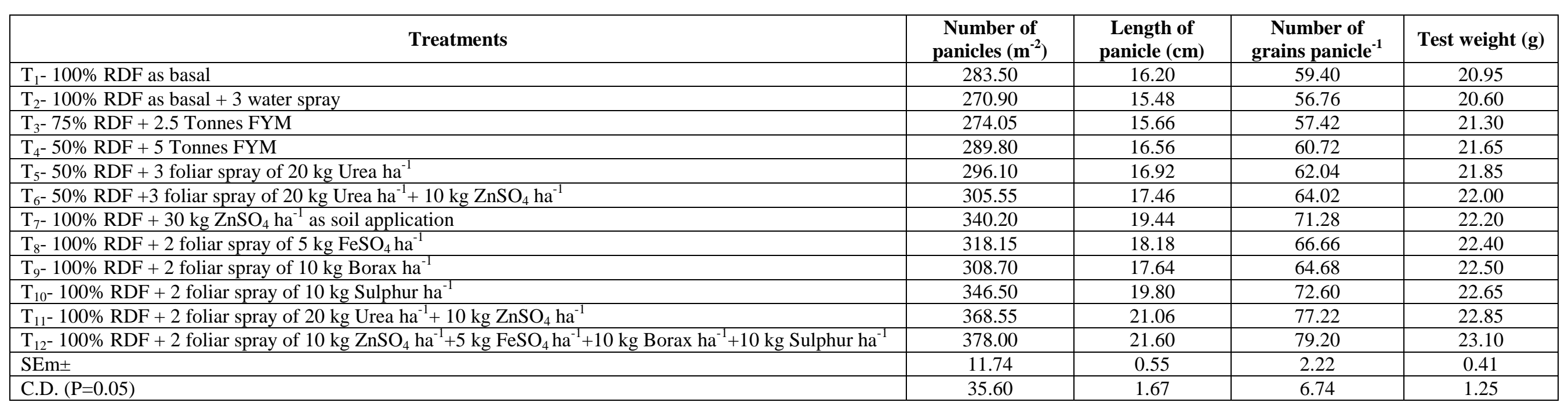

Table.2 Effect of various nutrient management modules on grain yield, straw yield and harvest index of rice

\begin{tabular}{|c|c|c|c|}
\hline Treatment & Grain yield $\left(\mathrm{q} \mathrm{ha}^{-1}\right)$ & Straw yield $\left(\mathrm{q} \mathrm{ha}^{-1}\right)$ & Harvest index $(\%)$ \\
\hline $\mathrm{T}_{1}-100 \% \mathrm{RDF}$ as basal & 23.20 & 31.92 & 42.04 \\
\hline $\mathrm{T}_{2^{-}}-100 \%$ RDF as basal +3 water spray & 25.20 & 33.76 & 42.70 \\
\hline $\mathrm{T}_{3}-75 \% \mathrm{RDF}+2.5$ Tonnes FYM & 22.50 & 31.68 & 41.53 \\
\hline $\mathrm{T}_{4^{-}} 50 \%$ RDF + 5 Tonnes FYM & 21.40 & 30.04 & 41.60 \\
\hline $\mathrm{T}_{5^{-}} 50 \% \mathrm{RDF}+3$ foliar spray of $20 \mathrm{~kg}$ Urea ha ${ }^{-1}$ & 22.60 & 32.96 & 40.72 \\
\hline $\mathrm{T}_{6^{-}} 50 \% \mathrm{RDF}+3$ foliar spray of $20 \mathrm{~kg} \mathrm{Urea} \mathrm{ha}^{-1}+10 \mathrm{~kg} \mathrm{ZnSO}_{4} \mathrm{ha}^{-1}$ & 24.00 & 33.28 & 41.83 \\
\hline $\mathrm{T}_{7^{-}} 100 \% \mathrm{RDF}+30 \mathrm{~kg} \mathrm{ZnSO}_{4} \mathrm{ha}^{-1}$ as soil application & 26.80 & 36.60 & 41.00 \\
\hline $\mathrm{T}_{8}-100 \% \mathrm{RDF}+2$ foliar spray of $5 \mathrm{~kg} \mathrm{FeSO}_{4} \mathrm{ha}^{-1}$ & 25.00 & 33.80 & 42.60 \\
\hline $\mathrm{T}_{9^{-}} 100 \% \mathrm{RDF}+2$ foliar spray of $10 \mathrm{~kg}$ Borax ha ${ }^{-1}$ & 25.20 & 32.52 & 43.66 \\
\hline $\mathrm{T}_{10^{-}} 100 \% \mathrm{RDF}+2$ foliar spray of $10 \mathrm{~kg}$ Sulphur ha ${ }^{-1}$ & 25.40 & 35.60 & 42.95 \\
\hline $\mathrm{T}_{11^{-}} 100 \% \mathrm{RDF}+2$ foliar spray of $20 \mathrm{~kg}$ Urea ha $^{-1}+10 \mathrm{~kg} \mathrm{ZnSO}_{4} \mathrm{ha}^{-1}$ & 27.50 & 37.40 & 42.32 \\
\hline $\begin{array}{l}\mathrm{T}_{12^{-}} 100 \% \mathrm{RDF}+2 \text { foliar spray of } 10 \mathrm{~kg} \mathrm{ZnSO}_{4} \mathrm{ha}^{-1}+5 \mathrm{~kg} \mathrm{FeSO}_{4} \mathrm{ha}^{-1}+10 \mathrm{~kg} \mathrm{Borax} \mathrm{ha}^{-1} \\
+10 \mathrm{~kg} \text { Sulphur ha }\end{array}$ & 29.10 & 41.00 & 41.50 \\
\hline SEm \pm & 0.80 & 0.78 & - \\
\hline C.D. $(\mathrm{P}=0.05)$ & 2.44 & 2.35 & \\
\hline
\end{tabular}


Table.3 Effect of various nutrient management modules on economics of rice

\begin{tabular}{|c|c|c|c|c|}
\hline Treatments & $\begin{array}{l}\text { Total cost of } \\
\text { cultivation }\left(\operatorname{Rs~ha}^{-1}\right)\end{array}$ & $\begin{array}{l}\text { Gross return } \\
\left(\mathrm{Rs} \mathrm{ha}^{-1}\right)\end{array}$ & $\begin{array}{l}\text { Net return } \\
\left(\mathrm{Rs} \mathrm{ha}^{-1}\right)\end{array}$ & $\begin{array}{l}\text { Benefit- } \\
\text { cost ratio }\end{array}$ \\
\hline $\mathrm{T}_{1-}-100 \% \mathrm{RDF}$ as basal & 17749 & 35820 & 18071 & 2.02 \\
\hline $\mathrm{T}_{2}-100 \% \mathrm{RDF}$ as basal +3 water spray & 18874 & 38680 & 19806 & 2.05 \\
\hline $\mathrm{T}_{3}-75 \% \mathrm{RDF}+2.5$ Tonnes FYM & 18737 & 34920 & 16183 & 1.86 \\
\hline $\mathrm{T}_{4^{-}} 50 \% \mathrm{RDF}+5$ Tonnes FYM & 19600 & 33190 & 13591 & 1.69 \\
\hline $\mathrm{T}_{5^{-}} 50 \% \mathrm{RDF}+3$ foliar spray of $20 \mathrm{~kg}$ Urea ha $^{-1}$ & 17482 & 35360 & 17879 & 2.02 \\
\hline $\mathrm{T}_{6^{-}} 50 \% \mathrm{RDF}+3$ foliar spray of $20 \mathrm{~kg}$ Urea ha $^{-1}+10 \mathrm{~kg} \mathrm{ZnSO}_{4} \mathrm{ha}^{-1}$ & 17832 & 37120 & 19289 & 2.08 \\
\hline $\mathrm{T}_{7-}-100 \% \mathrm{RDF}+30 \mathrm{~kg} \mathrm{ZnSO}_{4} \mathrm{ha}^{-1}$ as soil application & 18924 & 41310 & 22386 & 2.18 \\
\hline $\mathrm{T}_{8}-100 \% \mathrm{RDF}+2$ foliar spray of $5 \mathrm{~kg} \mathrm{FeSO}_{4} \mathrm{ha}^{-1}$ & 19124 & 38450 & 19326 & 2.01 \\
\hline $\mathrm{T}_{9^{-}} 100 \% \mathrm{RDF}+2$ foliar spray of $10 \mathrm{~kg}$ Borax $\mathrm{ha}^{-1}$ & 19099 & 38370 & 19271 & 2.01 \\
\hline $\mathrm{T}_{10^{-}} 100 \% \mathrm{RDF}+2$ foliar spray of $10 \mathrm{~kg}$ Sulphur ha ${ }^{-1}$ & 19699 & 39380 & 19681 & 2.00 \\
\hline $\mathrm{T}_{11^{-}} 100 \% \mathrm{RDF}+2$ foliar spray of $20 \mathrm{~kg} \mathrm{Urea} \mathrm{ha}^{-1}+10 \mathrm{~kg} \mathrm{ZnSO}_{4} \mathrm{ha}^{-1}$ & 18981 & 42350 & 23369 & 2.23 \\
\hline $\begin{array}{l}\mathrm{T}_{12^{-}} 100 \% \mathrm{RDF}+2 \text { foliar spray of } 10 \mathrm{~kg} \mathrm{ZnSO}_{4} \mathrm{ha}^{-1}+5 \mathrm{~kg} \mathrm{FeSO}_{4} \mathrm{ha}^{-1}+10 \\
\mathrm{~kg} \text { Borax ha-1 }+10 \mathrm{~kg} \text { Sulphur ha- }\end{array}$ & 21649 & 45170 & 23521 & 2.09 \\
\hline
\end{tabular}


The maximum test weight was registered with $\mathrm{T}_{12}(100 \% \mathrm{RDF}+2$ foliar spray of $10 \mathrm{~kg}$ $\mathrm{ZnSO}_{4} \mathrm{ha}^{-1}+5 \mathrm{~kg} \mathrm{FeSO} \mathrm{ha}^{-1}+10 \mathrm{~kg}$ Borax $\mathrm{ha}^{-1}+10 \mathrm{~kg}$ Sulphur ha ${ }^{-1}$ ) which was at par with $T_{5}$ and $T_{11}$ and significantly superior over rest of the treatments. The balanced doses of nutrients resulted increase in photosynthetic efficiency and its translocation towards sink (grains) which resulted heavier grains. Qian et al., (2009) and Reddy and Reddy (1989) have also been reported better test weight with balanced doses of nutrients. The grain yield was significantly influenced by various nutrient management modules. The maximum grain yield of $29.10 \mathrm{q} \mathrm{ha}^{-1}$ was recorded with $\mathrm{T}_{12}(100 \% \mathrm{RDF}+2$ foliar spray of $10 \mathrm{~kg} \mathrm{ZnSO}_{4} \mathrm{ha}^{-1}+5 \mathrm{~kg} \mathrm{FeSO}_{4} \mathrm{ha}^{-1}+10 \mathrm{~kg}$ Borax ha ${ }^{-1}+10 \mathrm{~kg}$ Sulphur ha-1) which was at par with $\mathrm{T}_{7}\left(100 \% \mathrm{RDF}+30 \mathrm{~kg} \mathrm{ZnSO} 4 \mathrm{ha}^{-1}\right.$ as soil application) and $\mathrm{T}_{11}(100 \% \mathrm{RDF}+2$ foliar spray of $20 \mathrm{~kg}$ Urea ha ${ }^{-1}+10 \mathrm{~kg} \mathrm{ZnSO}_{4}$ $\mathrm{ha}^{-1}$ ) and significantly superior over rest of the treatments (Tables 2 and 3). Those results may be attributed to the fact that balanced nutrient modules, resulted balanced availability of nutrients and their uptake resulting better sink capacity which ultimately increased the grain yield. Similar findings have also been reported by Qian et al., (2009) and Singh et al., (1998). The straw yield was significantly affected with various nutrient management modules. The maximum straw yield of $41.00 \mathrm{q}$ ha-1 was recorded with T12 $(100 \% \mathrm{RDF}+2$ foliar sprays of $10 \mathrm{~kg} \mathrm{ZnSO} 4$ $\mathrm{ha}^{-1}+5 \mathrm{~kg} \mathrm{FeSO}_{4} \mathrm{ha}^{-1}+10 \mathrm{~kg}$ Borax ha ${ }^{-1}+$ $10 \mathrm{~kg}$ Sulphur ha ${ }^{-1}$ ) which were significantly superior over other nutrient management modules. The balanced dose of nutrients increased all the growths characters viz., plant height, initial plant stand, number of shoots $\mathrm{m}^{-2}$, number of ear bearing shoots $\mathrm{m}-2$ as well as dry matter production which resulted increase in straw yield. Similar findings have also been reported by Kumar et al., (2005) and Malik and Kaleem (2007). Harvest index is the function of grain yield to the total biological yield (grain + straw). Harvest index was also influenced significantly due to various nutrient management modules. The higher harvest index was recorded with $\mathrm{T} 9$ $(100 \% \mathrm{RDF}+2$ foliar sprays of $10 \mathrm{~kg}$ Borax $\mathrm{ha}^{-1}$ ) treatment. Similar findings have also been reported by Muhammad et al., (2012).

On the basis of experimental result, it may be concluded that foliar spray of nutrients in an appropriate quantity with recommended doses of fertilizer (RDF) increases the yield attributing characters and grain and straw yields of the crop. This clearly shows that foliar application of zinc, boron and sulphur with RDF in rice crop increases yield attributes as well as yield of rice because of the availability of micro nutrients.

\section{References}

Anonymous, 2013. Agriculture Research Data Book, Ministry of Agric., Govt. of India.

Hollena, H., Didzwan, A.H. and Md. F.R. 2008. Effect of nitrogen fertilization management practice on the grain yield and nutritional quality of commercial rice. Malaysian J. Mathematical Sci., 2(2): 61-71.

Kumar, R., Shivani. G. and Kumar, S. 2005. Effect of $\mathrm{N}$ and $\mathrm{K}$ levels on growth of yield of hybrid rice. J. Appl. Bio., 15 (1): 31-34.

Malik, T.H., and Kaleem, M. 2007. Response of hybrid rice to levels and time of nitrogen application. Environ. and Ecology, 25 (4): 927-928.

Maurya, O.M., and Yadava, M.P. 1987. Performance of average seedling at different $\mathrm{N}$ levels and Rice Res. Newsletter, 12 (4): 9.

Muhammad, A., Shehzad, M.A., Fiaz, B.M., Tasneem, G.Y. and Munawar, I. 2012. Boron, Zinc and microtone effects on growth, chlorophyll contents and yield 
attributes in rice (Oryza sativa L.) cultivar. African J. Bio Tech., 11(48): 10851-10858.

Prasad, R. Rice-wheat cropping system. Advances in agronomy, 86:255-339 2005.

Qian Yinfei; Zhang Hongcheng, Lijie Wu Wenge, Guo, Zhenhua Chen Ye, Zhang, Qiang Dai, Qi Gen Huo, Zhong Yang, and XuKe 2009. Effect on nitrogen application rate on grain rice. Plant Nutrition and Fertilizer Sci., 15 (3):522528.

Reddy, R.S.G., and Reddy, A.K. 1989. Effect of level and source of nitrogen on rice. Indian J. Agron., 34 (3): 364-366.

Shekara, B.G., Shivakumara, G.B., Manjunath, B., Malikarjuna, N.,
Sudarashan, G.K. and Ravikumar, B. 2011. Effect of different level and time of nitrogen application on growth yield and nutrient uptake in aerobic rice (Oryza sativa L.). Environ. And Ecology, 29(2A):892-895.

Singh, R.S., and Singh, S.B. 1998. Response of rice (Oryza sativa L.) to age of seedling and levels and torrid of application of nitrogen under irrigated condition. Ind. J. Agron., 43(4):632635.

Singh, S.R., and Verma, L.P. 2006. Effect of source and method of phosphorus application on growth and yield and protein of transplanted rice (Oryza sativa L.). J. Environ. Ecol., 24(5): 315319.

\section{How to cite this article:}

Anand Mohan, Ankit Tiwari and Bhagwan Singh. 2017. Effect of Foliar Spray of Various Nutrients on Yield Attributes, Yield and Economics of Rainfed Rice. Int.J.Curr.Microbiol.App.Sci. 6(10): 2566-2572. doi: https://doi.org/10.20546/ijcmas.2017.610.301 